\title{
The Paliyars and Shiva Temples of the Caturagiri Hills, Virudunagar District, Tamil Nadu, South India and the Caturagiri Vazhinadaiccindu
}

\author{
V. Selvakumar \\ Department of Maritime History and Marine Archaeology, Tamil University, Thanjavur - 613010, Tamil Nadu, India; \\ selvakumarodi@gmail.com
}

\begin{abstract}
Caturagiri is a mountain located about $58 \mathrm{~km}$ to the southwest of Madurai in southern part of Tamil Nadu, South India. The mountain valley, with a reserved forest cover, has two shrines dedicated to Shiva, natural shelters with rock paintings, and caves and shelters considered to be the abodes of the Siddhas. Thousands of people from Tamil Nadu visit the Shiva temples of Sundaramahalingam and Sandanamahalingam located on the Caturagiri mountain on the new moon days, and it has become a popular pilgrimage and tourist destination. This area is inhabited by the Paliyars who used to primarily subsist through hunting-gathering till the 20th century. This paper discusses about the Paliyars of this region, history of the Caturagiri temple, the Saptur Zamindari, which patronized the Caturagiri temples, and the Caturagiri Vazhinadaiccindu, which is found in the British Library. It argues that the Siddha medicine system perhaps had the contribution of the hill people of Tamil Nadu, including the Paliyars, who do preserve and practice the traditional medicinal system.
\end{abstract}

Keywords: Caturagiri, Cindu, Palayakkarars, Paliyans, Paliyars, Poligars, Saptur Zamindari, Siddhas, Siddha Medicine, Vazhinadaiccindu

\section{Introduction}

Caturagiri (Sathuragiri or Chaturagiri or Caduragiri, $9.7346^{\circ} \mathrm{N}, 77.522^{\circ} \mathrm{E}$ ) is a mountain located about $58 \mathrm{~km}$ to the southwest of Madurai on the eastern-most boundary of the Western Ghats in South India (Figure 1). The mountain valley has shrines dedicated to Shiva, and natural caves and shelters considered to be the abodes of the Siddhas, which are famous for pilgrimage, mainly on the new moon day of each month in the Tamil Calendar. The author found a Vazhinadaiccindu--a genre of devotional song recited by the people during their pilgrimage by walk, on the way to the Caturagiri temple--at the British Library ${ }^{1}$. This paper presents the history of the Caturagiri temple, the Saptur Poligars (Palayakkarars) and the narrative details of the Caturagiri Vazhinadaiccindu, which was published in 1916. Vazhinadaiccindu is devotional song, sung by devotees during their pilgrimage by walk ${ }^{2}$.

\subsection{The Caturagiri Mountains: Environmental Context}

The Caturagiri is a large mountain with a deciduous forest cover, located on the south-eastern side of the VarushanaduAndipatti hill range, which is an offshoot of the Western Ghats (Figuers 1-2). The hill peak is more than $1200 \mathrm{~m}$ AMSL in height, and the temple is located in a valley, at an elevation of about 800+ m AMSL. Incidentally, the Kolli hills near Salem, which has the Shiva temple of Arapaliswarar, too has the name Caturagiri. Caturam means 'square' and giri means mountain in Sanskrit. The Caturagiri mountain of the Western Ghats that we discuss here, lies to the south of Saptur town (in Madurai district, $60 \mathrm{~km}$ southwest of Madurai) and to the northwest of Varrirayiruppu (in Virudunagar district, $78 \mathrm{~km}$ southwest of Madurai) in the southern part of Tamil Nadu. The mountain has a shrine dedicated to Shiva known as Sundaramahalingam temple, which has become very popular nowadays, mainly in southern Tamil Nadu. It also 
has a Shiva temple called Sandanamahalingam and many other shrines, and caves, which are considered to be the abodes of Siddhas.

The Caturagiri is the eastern-most hill peak in the continuous mountain range of the Western Ghats (Figure 2). There are four main streams draining the mountains and valleys around the Caturagiri mountain. One of the main streams is called Mangani Odai, which is close to the path leading to the Caturagiri temple. The temple is in the valley formed by the Caturagiri hill on the east and the main hill range on the west. These streams form the river Arjuna, which becomes part of the Vaippar river further east. The Vaippar river flows through Virudunagar district and finally joins the Bay of Bengal.

The Caturagiri hill can be reached from Saptur and Varrirayiruppu lying close to the foothills. Varrirayiruppu (Anglicised form Watrap) derives its name from the perennial water source from the Caturagiri hills. Varrira means perennial (which does not dry up) and Iruppu means settlement. Similarly, Saptur is derived from 'Sapa' means mat and "ootta" means spring in Telugu (urru in Tamil). The names of both the settlements reveal about the abundant natural water sources available around the hill area of Caturagiri.

\subsection{Archaeological Research on the Gundar Basin near the Caturagiri Hill}

The author undertook doctoral and post-doctoral research in this area, and research by various scholars brought to light a number of prehistoric and historical sites and settlements in the Upper Gundar Basin (Figuers 3-5) ${ }^{3}$. A few sites associated with the Paliyars were documented in the basin. Peter Gardner, an American anthropologist who visited the temple earlier, mentions about the existence of a copper plate among the Paliyars with regard to their traditional rights over the temple ${ }^{4}$.

The Paliyars offer traditional medicines to the local people, who visit these temples and they have extensive knowledge on the traditional medicine ${ }^{5}$. The Paliyar hunter-gatherers were the main agency of this hill area, and they have detailed knowledge of the terrain and hills, springs, rocks and tracks, animals and medicinal plants. Hence, their knowledge base is essential for understanding the hills and its resources, for the people from the plains.

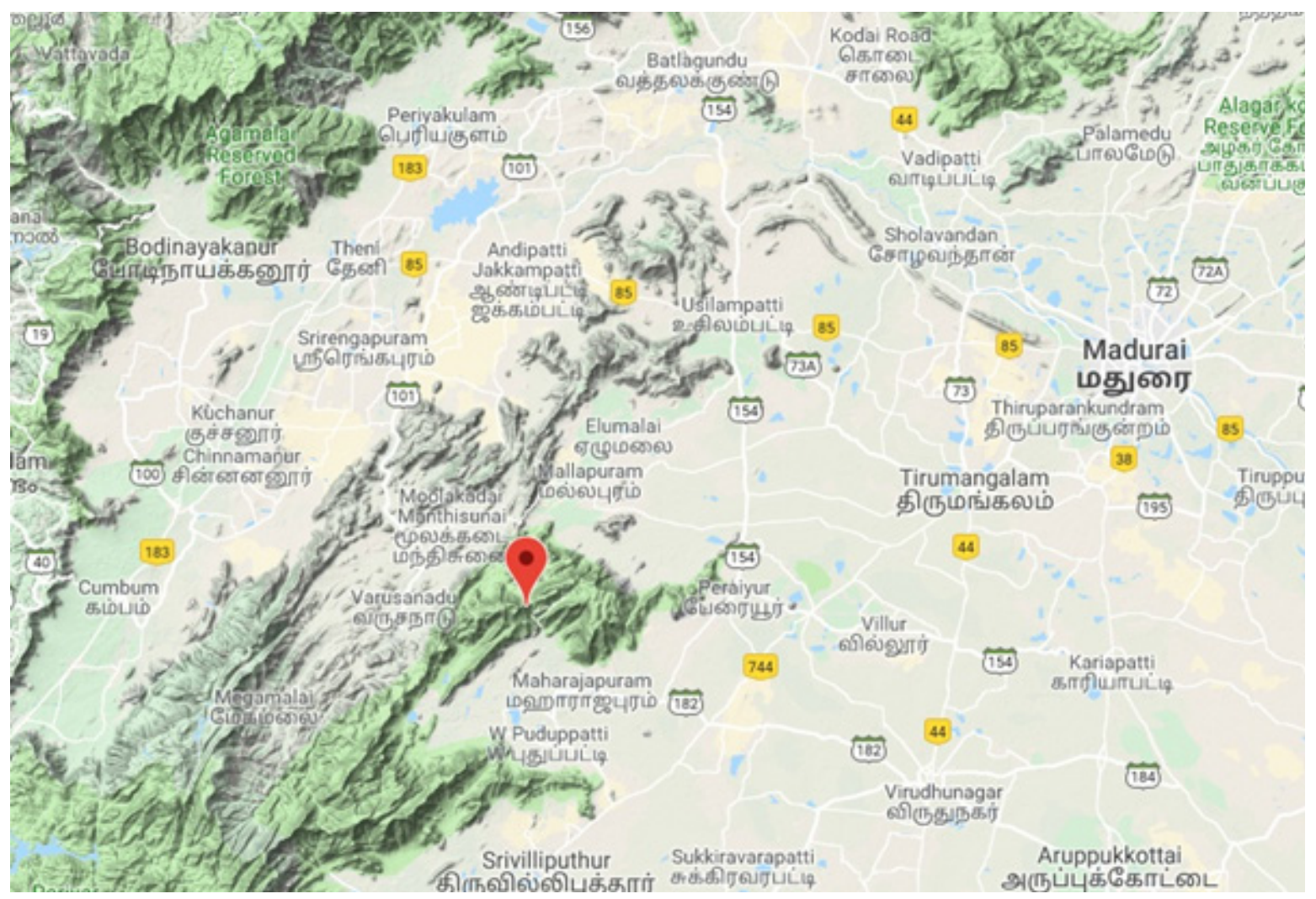

Figure 1. Location of Caturagiri Temple in Southern Tamil Nadu, Courtesy: Google Map. 


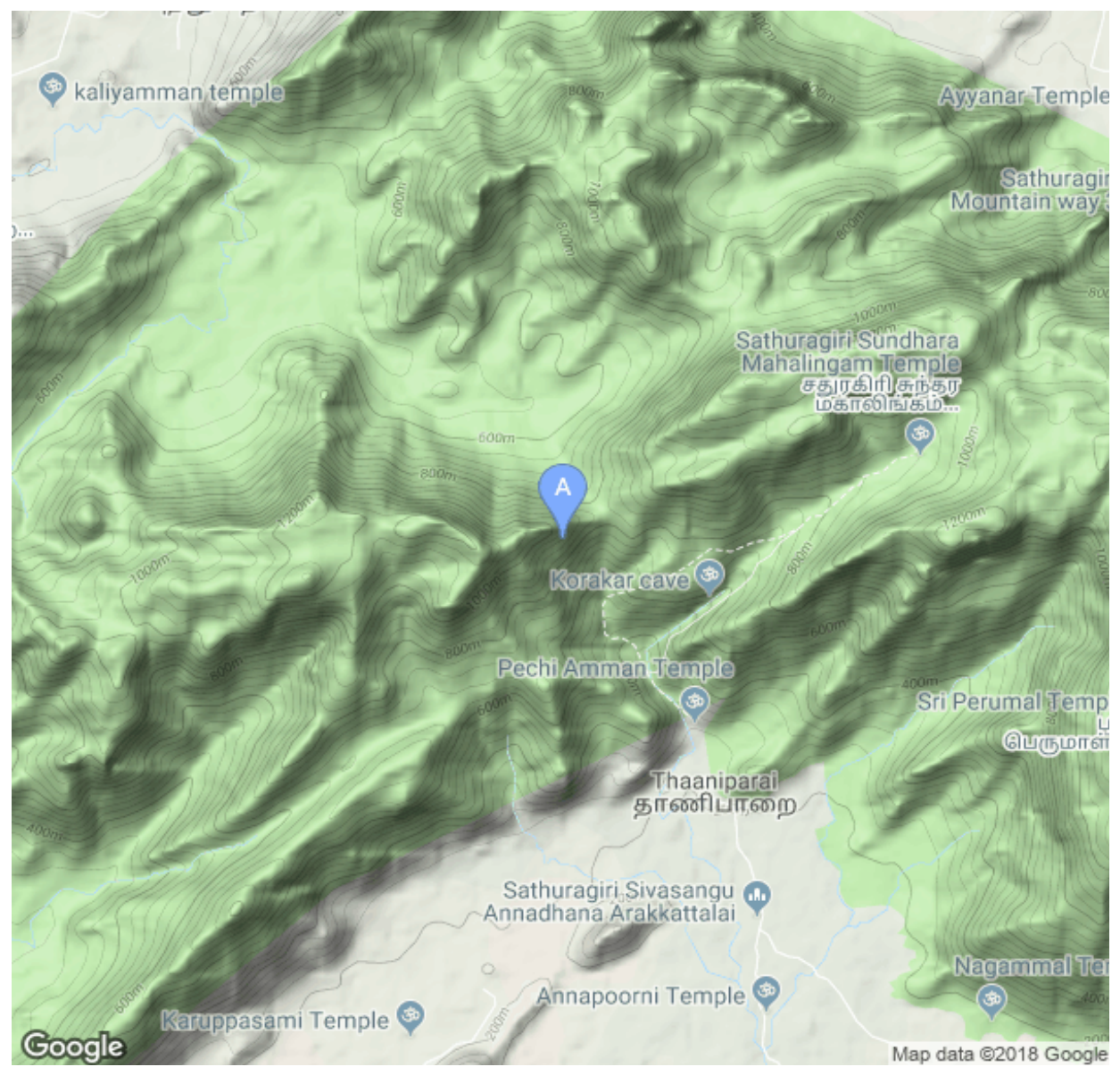

Figure 2. Contour Map showing the Route from Taniparai to the Mahalingam Temple Courtesy: Google Map.

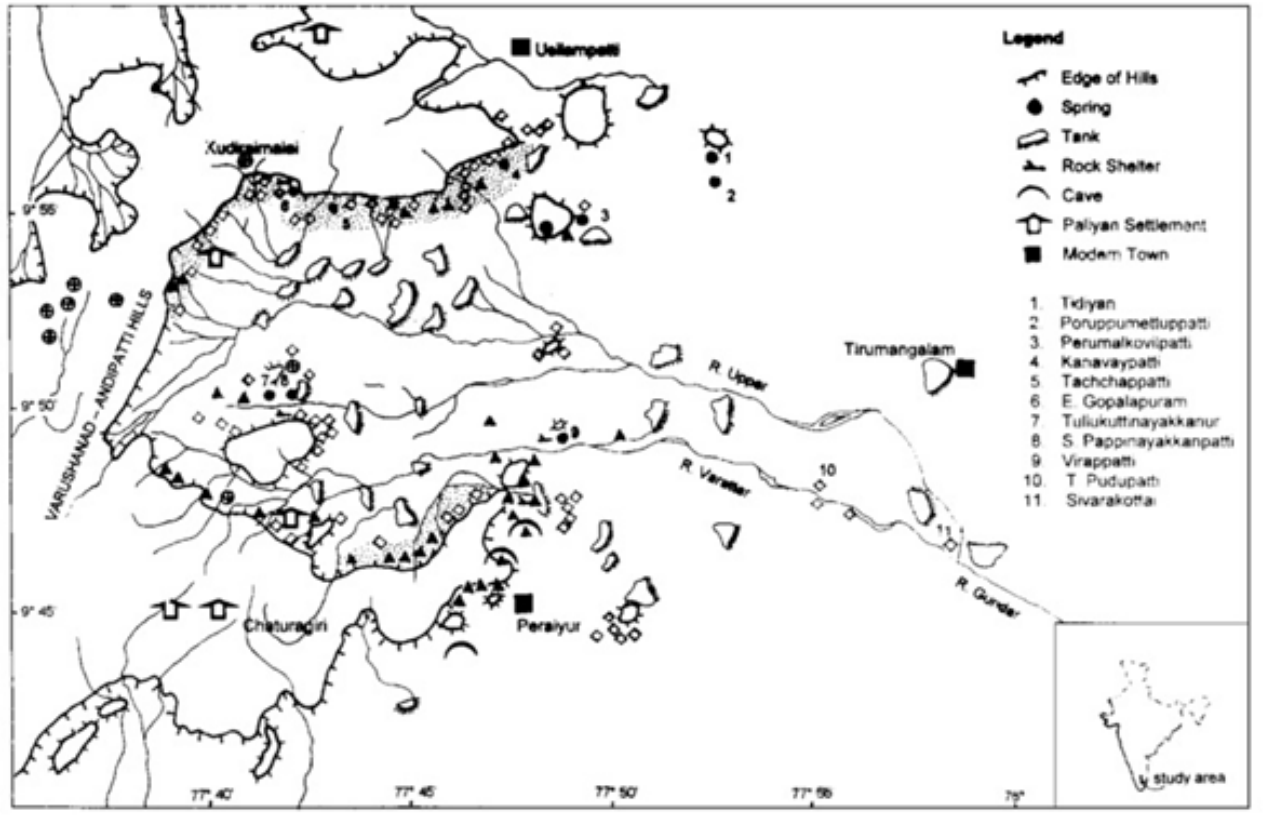

Figure 3. Microlithic Sites in the Upper Gundar Basin. 


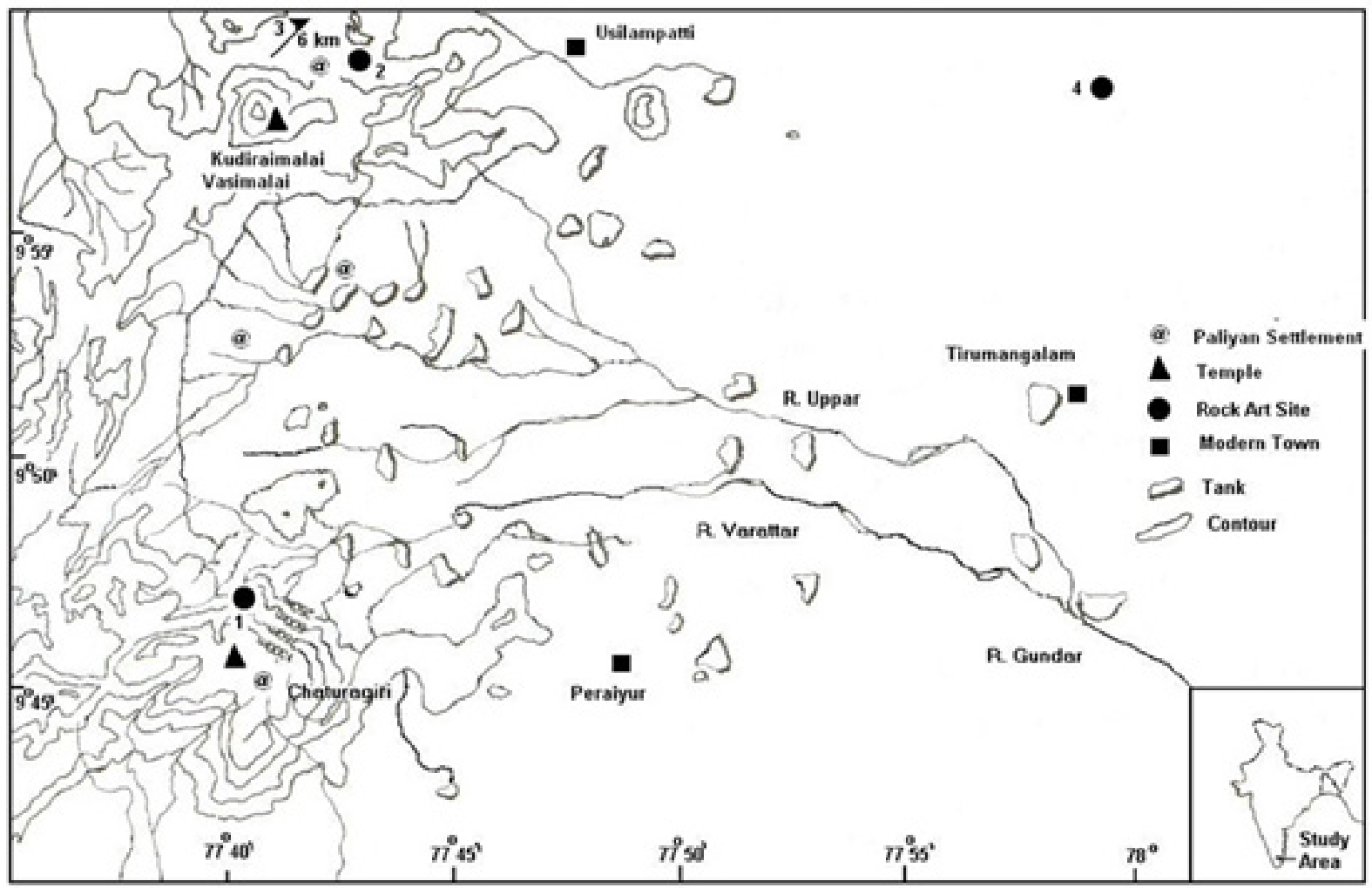

Figure 4. Paliyar Settlements in the Upper Gundar Basin.

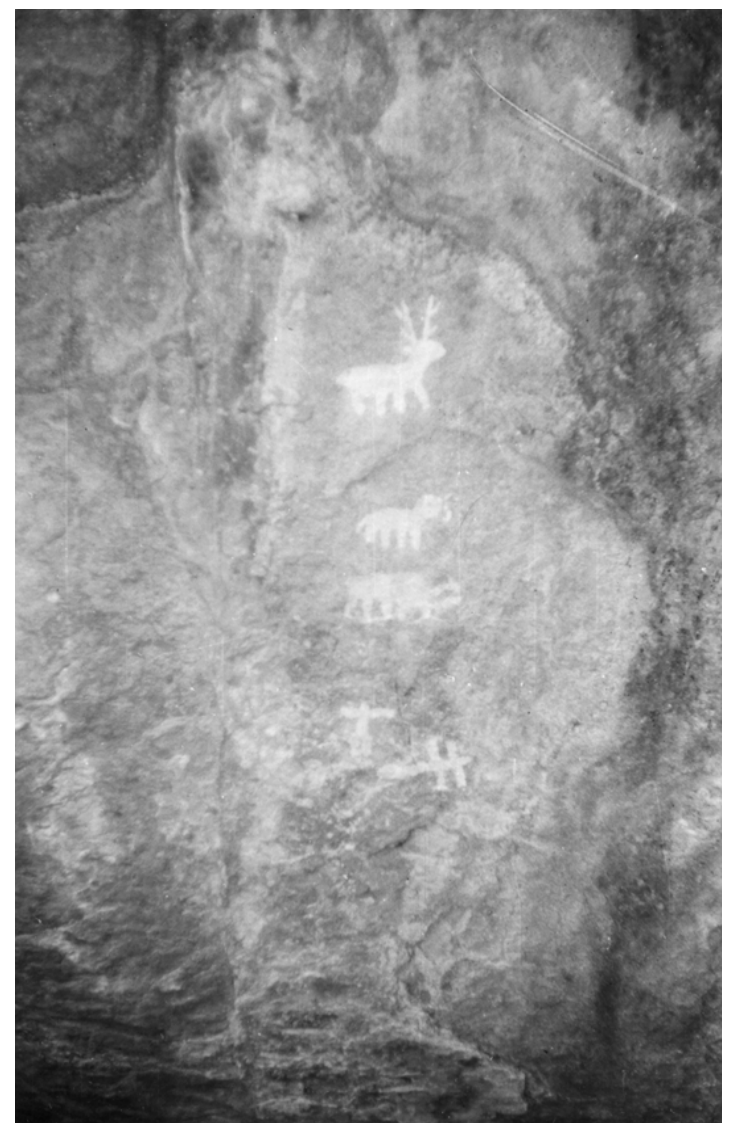

Figure 5. Rock Paintings at Kuliratti Cave, Caturagiri.

\section{The Paliyars of the Caturagiri and Varushanadu-Andipatti Hill Range}

The Paliyars are the native hunter-gatherer group living in the Caturagiri Hill area (Figure 5) ${ }^{6}$. The Paliyars live in many parts of Southern Tamil Nadu; they are found in the Palani hills, the Sirumalai hills and also in Tirunelveli region, and archaeological remains and rock paintings are found at some of these sites ${ }^{7}$. Their population in this area was less than 50 . I visited the temple in the 1990s; at that point of time, only a small group of people used to visit the temple and the forest department's restrictions were not there to visit the temple then. Nowadays a large number of people visit the temples, especially after 2000 the number of visitors increased many folds, and there are restrictions on the visitors.

The Paliyars live in several settlements and they are associated with several hill temples of this area; for example, Caturagiri temples, Mavuttu Velappar temple near Andipatti and Sastha Koyil near Rajapalayam. They interact with the local populations through several activities and means. Some of these groups live in the permanent settlements and some are semi-sedentary in nature. A few groups are considered to live in the forests without limited contacts with outside world. 


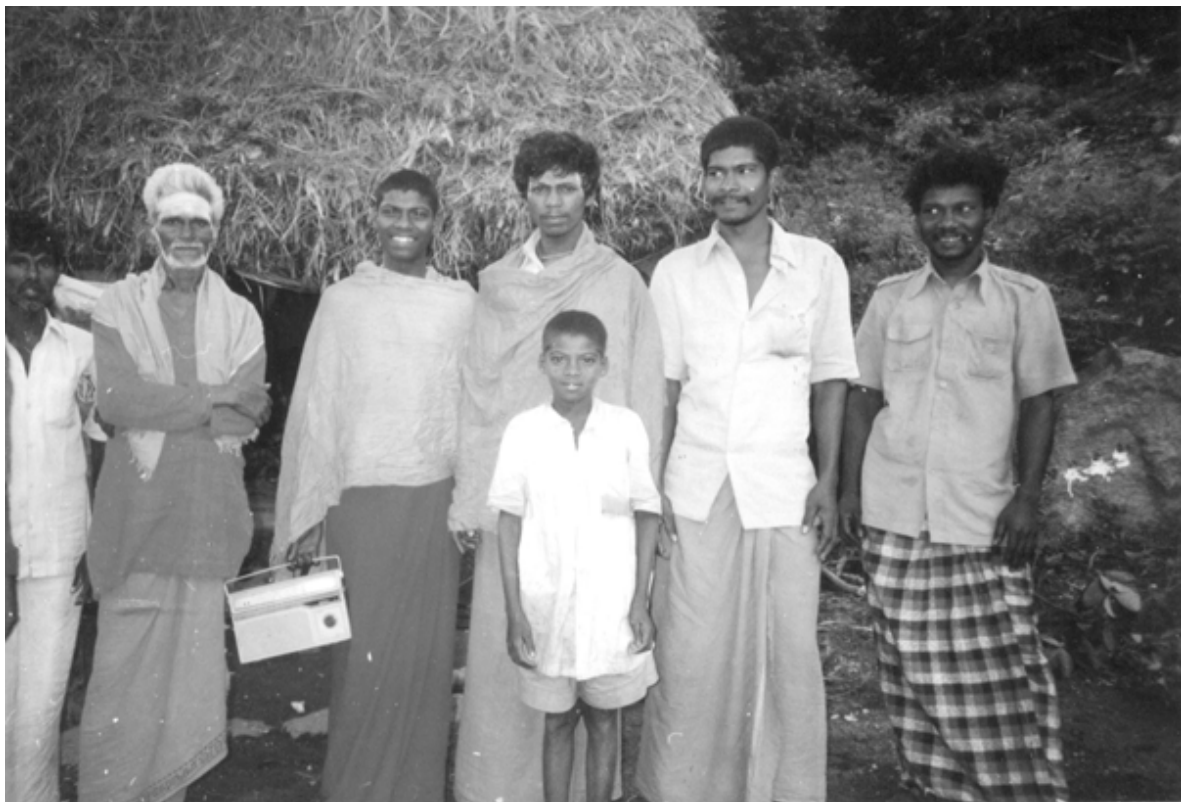

Figure 6. The Paliyars and Visitors at the Sundara Mahalingam Temple.

An important service that Paliyars offer to the local people is ethnomedicine services ${ }^{8}$ and they have detailed knowledge on the traditional medicine. During the time of festivals and new moon days the local people who visit the temples of the hill region get treatment on various ailments. It is possible that the Siddhas interacted with the Paliyars and obtained information on the various herbal medicinal plants available on the hills.

\section{Caturagiri Hill Temples}

The Caturagiri temple seems to date back at least to the late medieval period. The hill is well known for the important medicinal plants used in the Siddha medicine. There are oral traditions that the Tamil Siddhas lived here in the past. A Siddhar named Korakkar is associated with this hill, and a shelter on this hill is considered to have been inhabited by Korakkar. It is called Korakkar cave. Bhogar, who composed the work called Bhogar 7000, is considered to have links with the Caturagiri mountain 9 . The Sivalingam on the way to the hill is considered to have been established by Konganar, another Siddhar.

A few Tamil textual sources are available on the temple. Apart from the Vazhinadaiccindu song which is discussed in this paper, a few more works related to Caturagiri are preserved in the British Library and Roja Muthiah Library. One is Caturakiri Varnippu (means description of Caturagiri) and this work was composed by Gurusamy Konar. Perhaps, it was edited by Kuppusamy Naidu (the Tamil word 'Parvaiyittu" mentioned in the work can be taken to editing or proof checking) and printed at Ramachandira Vilasam Achchuyandirasalai and published by Pudumandapam Book House, Madurai, in 1917 and a copy of this work is available at the British Library. A work titled Caturagiri Magattuvakkummi is preserved in the Roja Muthiah library, published in 1925. Kummipattu is a song sung by women by dancing and clapping their palms, and this song praises the importance (greatness) of Caturagiri temple. Another work was published in 1940 as Sathuragiri Talapuranam ${ }^{10}$. This Talapuranam is perhaps a copy of the original work published in 1921. The 1921 publication of Talapuranam available in Roja Muthiah library mentions that it was published based on the old records, by the order of Caturagiri Kattari Nagaiyya Kamarajendra Ramasamy Kamayya Nayakkar. Gurusamy Konar is the publisher of these works and several publications came out of his efforts and he was the proprietor of Pudumandapam publication house. Another work composed by Konkanar, perhaps the Siddhar, was Caturagiri Anandavalliamman Navarattiri Tottiramalai. This work, recited during the Dussera festival, was also published by the same agency in 1917, and is available at the British Library. For many of these works, encouragement might have been given by the Saptur Zamindar, who had an important role in the construction and promotion of this temple. The earliest published account of Caturagiri temple is available in the Madura District Gazetteer ${ }^{11}$. The Madura district Gazetteer mentions that the hill "is declared to be even now the residence of celestial sages and is a favourite place of pilgrimage" ${ }^{12}$. 


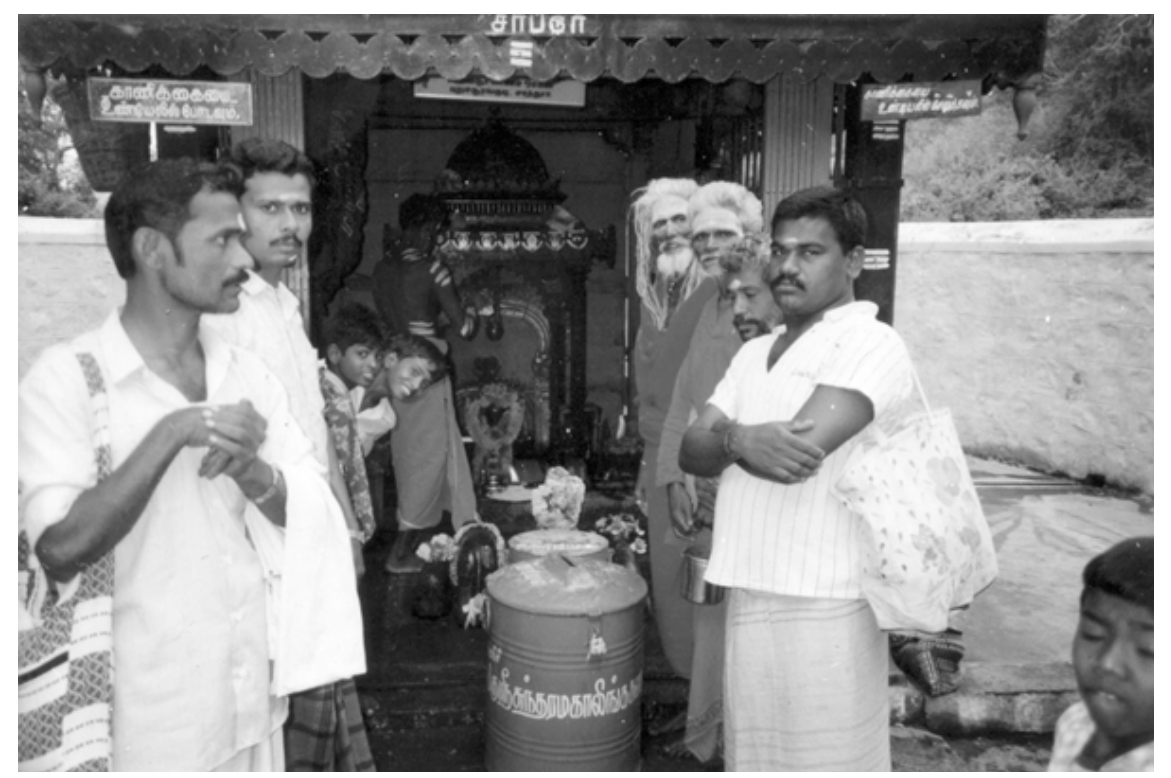

Figure 7. People from the plains offering worship at Mahalingasamy Temple 1990s.

Much earlier source related to the temple is found in the copper plate inscriptions. The Sandaiyur copper plates (one dated to ca. 1675 and another, 17th century CE) mention Caturagiri Sundaramahalingam and Krishnamurty as divine witnesses to the rights given to some people in the copper plate grants ${ }^{13}$. The first name obviously refers to the Caturagiri temple; the latter name Krishnamurty perhaps refers to the Vasimalai Vishnu temple; another hill temple located further north of the Caturagiri. Therefore, it appears that the temple had come into existence at least by the 17 th century CE.

On every new moon day, several thousands of devotees visit the temple (Figure 7), and during the month of May (Tamil month of Adi) several lakhs of pilgrims throng the temple. The temple can be reached through about 5 to 6 hours of trekking and could be accessed from Varrirayiruppu as well as from Saptur. The passage from Varrirayiruppu is easier to trek, but the pathway from Saptur is steeper and slightly tougher for trekking. The Caturagiri area comes under the protected reserve forest of Tamil Nadu Government. There are two Shiva temples, known as Sundaramahalingam and Sandanamahalingam temples. A small group of Paliyars, a hunter-gatherer group, lives in this area. There are a few caves and rock shelters with paintings, possibly of historical period ${ }^{14}$.

\subsection{Talapuranam}

On the origin of the Mahalingaswamy temple, there are a few versions of a story. A story, says that the Paliyars were grazing the cows owned by the people from the plains and one day a cow returned home and gave no milk. The local people reported that the Paliyars used to graze the cattle of the local people (agro-pastoral groups), in the dry seasons, in the hills, and then hand them over to the owners. The owner of the cow, which did not give milk, scolded the Paliyar and on the next day, the Paliyar saw the cow offering its milk on a stone linga and then realised about the divine nature of the spot and a temple was built at the spot, later. This is a common motif used in the Talapuranams of many temples of South India, and a similar version was adopted for the Caturagiri temple too. There are other versions of stories on the origin temple. Another story associated the origin of the temple with a person called Pachchaimal from the village of Kottaiyur near Caturagiri.

Peter M. Gardner, who records about another story related to the origin of the temple, mentions about the finding of a linga by a wandering ascetic on the hill; on being an ascetic, he placed the responsibility of offering pooja (worship) to the Paliyar man, whom he came across in the forest. Since then the Paliyars were the priests of the Shiva temple; when the people from the plains came to the shrine in large numbers, a dispute arose over the priesthood. This dispute was resolved by the ancestors of the Saptur Zamindars and they gave the rights of the Paliyars on a copper plate ${ }^{15}$. The whereabouts of the copper plate is not known.

\section{The Poligars/Palayakkarars and Zamindars of Saptur}

The region of the Upper Gundar Basin, which lies to the north of the Caturagiri mountain and to the east of the Varushanad-Andipatti hills, has a few Shiva temples dating back to the times of the medieval Pandyas. There are medi- 
eval inscriptions in the temples at Tirumanikkam, Peraiyur and Tevankurichchi, in this region. However, intensive occupation of this region with new settlements began in the late medieval period and the population increased in the area adjacent to the hillocks, mainly in the time of the Nayakas, after the $15^{\text {th }}$ century. The Nayaka migration is often attributed to the pressures caused by the Muslim migrations and their political ascendancy in the Deccan region. However, there could be other factors behind this migration. Not many early inscriptions of the Nayakas are available in the Upper Gundar Basin region. The village of Elumalai and Saptur, and a few other temples in this region have evidence of later period temples; mostly Vishnu or Perumal temples, and a few inscriptions, sculptures and hero stones.

Saptur is an early poligar seat and settlement of Southern Tamil Nadu. The poligars of Saptur belong to the Rajakambala Nayakkar community. They are described under the Thottiyanayakar caste by Edgar Thurston and Rangachari ${ }^{16}$, who compiled an account of castes and tribes of South India. The viceroy of the Vijayanagar empire for Madurai, Vishwanatha Nayakka ruled from 1535 to 1544 , and he was the founder of the Madurai Nayaka dynasty. It is reported that he divided Madurai territory into 72 palayams and Saptur is considered one of these Palayams ${ }^{17}$. Similarly, it is reported that Madurai town had a fortification with 72 bastions, and each of the 72 Palayams was given the responsibility to defend these bastions. The early history of Saptur is shrouded in mystery, since documentary evidence is lacking. However, from the Colonial period, more particularly from the $18^{\text {th }}$ century, we do have a number of references.

The poligars of southern Tamil Nadu are divided into Telugu and Marava poligars on ethnic grounds. The forefathers of Kattabomman, who resisted colonial rulers, had established around Panjalankurichi near Tirunelveli. The clashes between Kattabomman and the English Collector Jackson was inquired through Ramanathapuram Enquiry Committee. Later Kattabomman formed a confederacy against the British rulers. The Marudu brothers (Marudu Pandiyar) and other Poligars had already established themselves against the colonial rulers. The poligars of Saptur and Ezhayirampannai too joined this confederacy against the British ${ }^{18}$. It is claimed that the Saptur Poligar gave trouble to the people and officials who were looking after the administration in 1799, when the Palayam was annexed by the British ${ }^{19}$. In 1795, the Poligar of Saptur Kamayya Nayakkar did not give tribute to the British and was involved in irregularities, according to the account of the British, and a reward was offered for his head in 1799 , and it seems that the poligar escaped to the hills and he was captured in July $1800^{20}$. And Later, after a trial by a board of officers, he was executed on October 1800. Another version records that he cut his own head and did not surrender to the British. It is possible that he escaped to the Caturagiri hills and was supported by the Paliyars. Under the British occupancy, S.R. Lusington was appointed as the collector for the southern poligars in 1801. The estate of Saptur was given to the poligar's son in 1803 and sanad (deed) was given and thus the Permanent Settlement was implemented in May 1803. Saptur Estate was transferred from Tirunelveli district in $1859^{21}$. Ramasamy Kamayya Nayakkar II, who was the Zamindar of Saptur, was born in 1849 . He had six wives and two of them were married through the practice of Kattari wedding. Kattari means sword. The Kambala Nayaks had a peculiar system of marriage; in which, if the bride is from lower class, the bridge groom is represented by the sword, Kattari. The Thali is tied in the presence of sword ${ }^{22}$. Ramasamy Kamayya Nayakkar II created a garden of five square miles ${ }^{23}$. The Zamindar, who was also a Tamil scholar, died in 1886 and there were disputes over the Saptur estate and land among the wives, after his death ${ }^{24}$. There is one Caturagiri Kattari Nagaiyya Kamarajendra Ramasamy Kamayya Nayakkar mentioned in the Stalapuranam and perhaps, he was in power when many of the religious texts related to the temple were composed and his name has the prefix Caturagiri. This Zamindar was probably the same as Ramasamy Kamayya Nayakkar II or it could be his son.

It appears that the Saptur Zamindar's intensive involvement in the Caturagiri hills might have begun, when he was reported to have fled to the hills in the 1800 . They seem to have started their pilgrimage to the hill temple in the nineteenth century and one of the members of the family had the name Sundaramahalingam. The temple at Caturagiri seems to have been constructed by the Zamindar family. There are also stories associated with a Zamindar called "Talaivetti Nayakkar", who capitated the heads of thousands of people. There is also shrine associated with a Paliyar lady, who became a goddess, had association with the Zamindari. Later, the lands of the Zamindari and the temple administration were given to the government. The descendants of the Zamindar live at Saptur and the Periya Raja was interviewed by Peter Gardner in the twentieth century, and by the author in 2000 .

\subsection{Caturagiri: A Colonial Hunting Ground}

The hill areas of Varushanadu-Andipatti including the Caturagiri hill areas became a hunting ground for games as sports and entertainment. There are several wild animals 
in the hill areas, which border the Varushanadu-Andipatti hill range and they migrate into the valley plains. There is evidence for hunting activities in this area from the early times and evidence of wild animals has been reported from the excavations at the site of S. Pappinayakkanpatti ${ }^{25}$.

The railway time table Illustrated Guide to the South Indian Railway published by Higginbotham and Co., in 1900 mentions under the listing 'Sport' that in Saptur and Elumalai Zamindaris "good shooting can be had, deer, bison and wild boar being fairly plentiful. Permission to shoot must be obtained from the Zamindars. Shikaries and Collies can be hired at the spot" 26 .

The people of the local villages used to visit the hills mainly for hunting, and it was reported that some of the people had country guns. In the 1990s, I could see the blood and evidence related to the hunting undertaken on the hills by some parties. The restrictions of forest department became more in this area only after the late 1990s, when a large number of people began to visit this area.

\section{CaturagiriVazhinadaiccindu}

\subsection{Cinduppattu Genre}

Cindu is a popular genre of folk poetry of the Tamil region $^{27}$ and often it is associated with the Kavadi ritual procession and pilgrimage (Kavadi Cindu). Kavadi is a ritual object consisting of a wooden bar and an arch made of wood above, and it is carried on the shoulder. Kavadi was perhaps a transformation of a device once used for carrying commodities over shoulder across a long distance. Kavadiccindu is perceived as a popular and subaltern form of musical and literary tradition ${ }^{28}$. Many Cindu songs were composed during the colonial times on various themes in Tamil Nadu. This tradition was adopted by the Tamil poet of Annamalai Reddiyar, and Subramanya Bharatiyar has composed Cindu songs ${ }^{29}$. Cindu was a popular medium for expressing any type of cultural events and historical episodes, apart from devotional poetry. Innumerable Cindu songs were produced in the colonial times and they are preserved in many libraries across the world. Annamalai Reddiyar (1865-1891), who was a Tamil poet, composed several Cindu songs on Murugan or Subramaniyan, and they have become very popular. He was born near Cennikulam near Sangarankovil. The Kavadi Cindu songs are sung during the time of carrying kavadi to the temple of Murugan, more particularly, when they visited the temple at Palani ${ }^{30}$. There are debates if this was a popular or classical form literature; in fact, Cindu gave a simple format of poetry and folk form, so that people could express their ideas and document their perceptions, with ease and without the constraints of literary and musical grammar structures ${ }^{31}$. The Cindu songs of Tamil traditions seem to have influenced Sinhalese Cindu tradition in Sri Lanka ${ }^{32}$.

The Caturagiri Vazhinadaicindu song was published as a small booklet and a copy of this song is found in the British Library. The song describes about lord Shiva, the hills and the roadways and the route from Virudunagar leading to the temple. Since the composition of the Vazhinadaiccindu was supported by the people from Virudhunagar, it describes the route from Virudhunagar to Caturagiri.

The Vazhinadaiccindu was composed by Kandasami Nadar and was printed by S.K.M. Ulagaiyya Nadar, who was involved in coconut trade at Virudunagar. It was printed at Virudupatti Ramalinga Gurukkal's press in 1916 (Figure 8). There is another Cindu song on Caturagiri temple, composed by T. Kuppusami Naidu, available at Roja Muthiah Library in Chennai, which was published from Chennai in 1905. The content of that Cindu song is not known, since it has not been seen by the author of this paper. There is also a patikam (hymn) on the Caturagiri temple, published in 1921. Now we shall look into the structure of the cindu song and its main content, briefly.

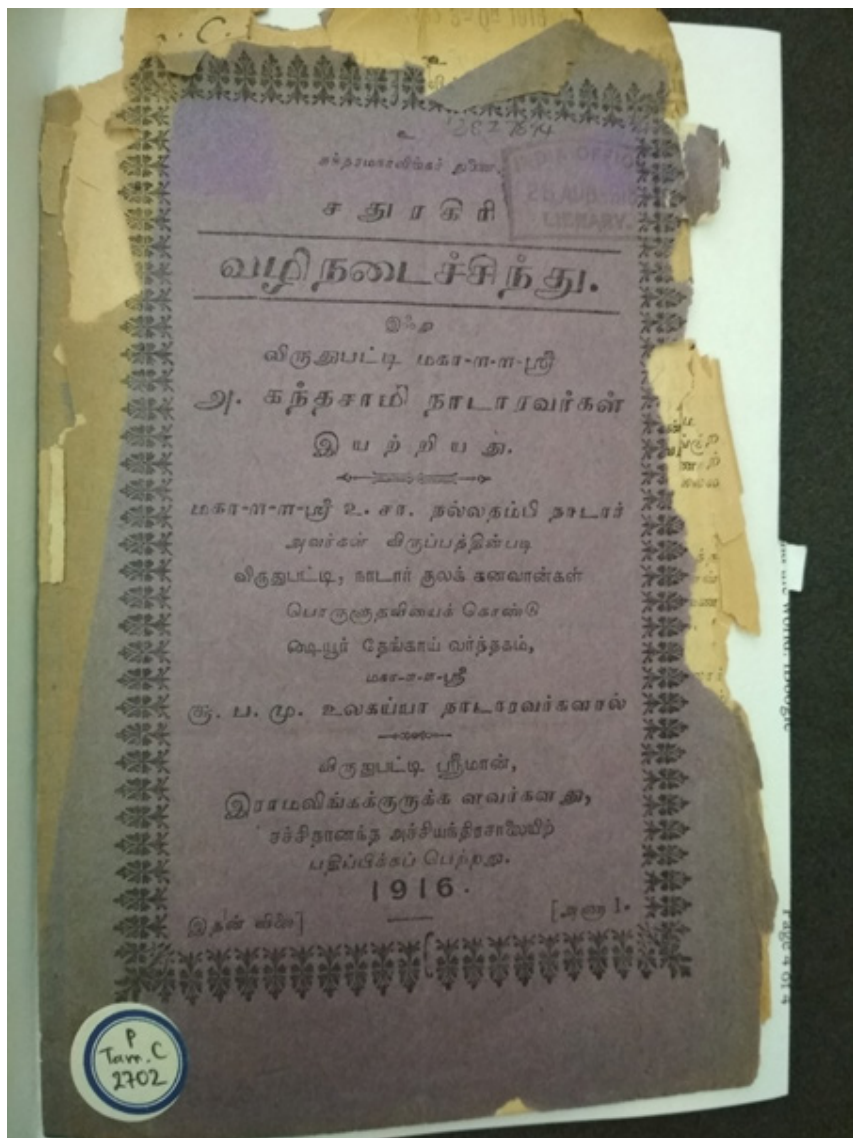

Figure 8. The cover page of the book Caturagiri Vazhinadaiccindu Courtesy: British Library. 
The Caturagiri Vazhinadaiccindu is in pentameter ("seer" in Tamil means meter) and the cindu genre, normally has 8 to 24 meter/seer, and here in this song, only five meters are present. We could suggest that the structure adopted is very simple here.

The Cindupattu is composed as a narrative exposition by the heroine (talaivi), explaining about the temple to her friend (tozhi). For each stanza, the tempo (mettu) of the song is mentioned, in terms of another popular cindu song of that time.

\subsection{Invocation}

In the composition of poems and long literary works in the Indian and Tamil traditions, at first support of a god by the composition of an invocation song; then the poems related to the main theme are composed. The invocation in the Caturagiri Vazhinadaiccindu is in the name of lord Ganesa.

\subsection{Narrating the Beauty of the Lady Companion (Tozhi)}

After the invocation, in the name of lord Ganesa, the beauty of lady companion is praised by the heroine. The title of this section is "The heroine narrating the beauty of her friend". The tempo (mettu) is mentioned as same as adopted in the song of "Mamagal Meviya Perainagar", which was perhaps another popular cindu song. It has five stanzas in pentameter, i.e. each stanza is with five lines or seer.

\subsection{In Praise of the lord Shiva at Sundaramahalingam Temple}

The next section contains 13 stanzas in pentameter. In this section, the heroine explains the fame of lord Sundaramahalingam to her friend. The consort of Sundaramahalingam, Anandavalli, and the concept of Lingodhbhava, in which Vishnu and Brahma could not locate the feet and head of Shiva, respectively, is specified, Ganesha and Murugan, the puranic story of burning tripuras are also presented. This section praises Siva explains his superiority over other gods and several puranic stories briefly.

\subsection{The Prosperity of the Caturagiri Hills}

This section, which praises the wealth of the Caturagiri hills, is titled as "Wealth of the Caturagiri". It is in the tempo (mettu) of the Cindu song "Ennadi nan perra mangai", which was composed by Annamalai Reddiyar. It has six stanzas, again in pentameter.
Here the scenario of the Caturagiri hill is narrated. The Kuravars drink toddy, prepare the garlands and beat the drums. The animals of tiger, kadaman (Rusa unicolor) and pulliman (spotted deer) found in the hills are mentioned.

I have visited the hills, twice and had met the Paliyars and have observed them the hill milieu. The poem uses the label Kuravars to refer to the hill people. It mentions that the Kuravars sing and dance. I have not seen the Paliyars dancing and they are very shy by nature. The poet perhaps explains about an imaginative scenario. This in a way highlights how we need to be careful about the interpretation of the motifs seen in the literature, while using them for historical reconstruction. Sometimes, such literary motifs are used merely for poetic embellishments.

\subsection{The Wealth of the Caturagiri Temple}

The next section speaks about the wealth of Caturagiri temple. Here the tempo is mentioned as similar to that of "Manju nigar konthalam minnu". It has four stanzas in pentameter. It talks about a tall tree with seven types of leaves. The bark, leave, flower and fruit of this tree could cure all diseases. Offering of curd, fresh ghee and three fruits of mango, jackfruit and banana is spoken. The offering of punugu (perfume from Civet cat), savvathu (aromatic substance from trees) and paneer (Rose water), in the performance of pooja at the temple creates strong fragrance. The poem mentions that women come to the temple seeking blessing of children. People, who got male child, came to fulfil their vows.

\subsection{The Prosperity of the Pathway to the Caturagiri Hill}

Here in this section, the heroine explains the wealth of the resources found on the way leading to the Caturagiri temple. It is in tetrameter and has 14 songs. It is in the tempo similar to that of "Telluthamizhukuthavu Seelan", which is a kavadiccindu song composed by Annamalai Reddiyar.

At first it mentions about the temple in Virudunagar, and the float (teppam) created by the community of Nadars in Virudunagar. The Teppakkulam is an important landmark in Virudunagar.

After the Mottaipillayar temple, it refers to Magamaikadai. Magamai was a type of contribution collected from the shop owners; the collected fund is used for various welfare activities. Offering of buttermilk and cold water to the visitors by the merchants is praised. It mentions about the temple of Siva in which lord Sokkalingar was present. There is a Sokkanathar temple at Virudunagar to the 
west of the Teppakkulam even today. Angayarkanniammai is the goddess here, according to the poem.

There is a temple of Ganesha established by Velayudha Devan. It mentions about a Magamayi temple. Then the Mariyamman teradi (Chariot base) is spoken. The Sala or school where the students of Kshatriya Nadar get training through Tamil and English languages is referred to. The image of Ganesha beneath the pipal tree, the Chettiyar tank and the Ayyanar temple worshipped by the community of Devars are mentioned.

\subsection{Nondiccindu}

Nodiccindu is a type of poem which has three words in a seer (meter or line). Here a brief description of the highway and the landmarks are mentioned.

After the south Virudunagar, we came to Sangaranarayanapuram; and around the village of Pavali, we see the paddy fields; then Mallaiya Nayakkanpatti, Sadaichipatti, Naranapuram, and the wealthy Kundilipatti, Sinappareddiyapatti, Puthuvur, Sengunrapuram, and a Nandavanam (garden for supplying flowers to temple) on the west, and the village of Ericcanattam with a river and tanks are mentioned. The Mangammalsalai, the road laid by Rani Mangammal to Srivilliputtur is mentioned. This road leads from Tirumangalam to Srivilliputtur.

Tungauttirappanayakkanpatti is referred to next. Karisakulam, Mannalarasapatti Kanavai (pass), Kottur Kanavai, Settiyakurichi Kanavai, Thambipatti, Ganapathisami Samathi (burial temple), the samathis of many people, who reached the foot of the lord of Caturagiri, and a Pallivasal (mosque), and Sivayogasami Madam (Mutt) are described as the landmarks on the way.

Maharajapuram was a settlement on this route and it exists even today. Barrister office (court) is mentioned at Maharajapuram, Police station where officers/employees live, and Mandithoppu (a grove of monkeys) are spoken. After a river crossing, Vandipannai and Tanipparai, Tall Kudiraiurru (a spring), Padivettupparai (a rock), Attiyurru (a spring) where Devars devotionally bathe, the curved Konavasal Medu (a raised area), Korakkar Kunda and Ettilingam (a Sivalinga), which was worshipped by Konganar, Ganapathy Samikal, Pasumithi, Pasukkadai, Neyyakdai (Ghee shop) Rattinasamy dharmam (Endowment), where water was offered, Navalurru (spring of Jambolan tree), Pambukkenithozhu (a place with a well and cattle shed), Pudupasukkadai, and Palavadi Karuppasamy temple are mentioned. The shops in front of the Karuppasamy temple in a row are mentioned. Then, Pechchiyamman temple, where the young goddess wears bangles, and the devotees obtaining sacred ash Prasad is mentioned. The Nadars of the villages of Usilampatti, Sivakasi, Mangaravu, Kalpothu, Virudupatti, Kallupatti, Attipatti, Saptur and Chinayapuram visit the area and dine in the shelters or hostels. The cavadi (public building) of Devanga Chettimar of Mutturamanpatti is mentioned. Virudhaidevar madam (Mutt of Devar from Virudhunagar), Kuluchandai Chettiyar building, Mayandiasari Madam (Mutt of Mayandi, the carpenter), Subbaiyanasari madam (the Mutt of Subbaiyyan, the carpenter), people's residences are referred to.

People who tonsure their head as part of their prayers. Kattari Kamayavel's bungalow, the Saptur Zamindar, Vattirayiruppu madam, Paliyar madam are mentioned. The police staff that work like philosophers and the Ukkiranam or the storehouse or treasury of the temple, Navarattiri Kottagai, the shed for Navaratri festival are referred to. The final section titled as Happy Enjoyment concludes with a happy note and seeks the blessings of the lords of Sandanamahalingam and Sundaramahalingam shrines for the welfare of all living beings.

\section{Discussions and Conclusions}

One of the early sources on the Caturagiri temple is the Talapuranam published in 1921. This along with the CaturagiriVazhinadaiccindu, published in 1916, is a proof that some of the information that we have on this temple is as old as the early twentieth century and people had begun to visit the temple in a large number at least from that time. The temple might have come up in the Late Medieval period, although we cannot be very specific about the century in which it came into existence. The use of the hill area might have begun in the prehistoric times, especially by the hunter-gatherers of the neighbouring Gundar and Vaippar river basins ${ }^{33}$. The Paliyars living in this area appear to be the original inhabitants of the mountains, and they had interactions with the local people from the plains from the historical period. With the expansion of agriculture and pastoralism in the Iron Age, reducing the animal resources on the plains, the hills were used as a source of wild-game hunting ${ }^{34}$. This sport of hunting was allowed in the hill areas, in the early $20^{\text {th }}$ century with the permission of Saptur and Elumalai Zamindaris, as revealed by the South Indian Railway guide, mentioned earlier. In addition, the knowledge of traditional medicine of the Paliyars was much sought after by the people from the plains to cure their diseases. I could see that the Paliyars offering medicine to the people from the plains, when they visited the Chaturagiri and Vasimalai temples, in the 1990s. Some of the Siddhars (Siddhas) might have utilised the knowledge of 
the Paliyars and validated and documented the information on traditional medicine as texts in the form of palm-leaf manuscripts. The movement of people as part of pilgrimage to the hills boosted the commercial activities related to the consumption of resources for the performance of poojas, and several goods could also be sold to the visitors. The Vazhinadaiccindu mentions about the shops located on the way to the hills. Thus, the commercial agencies might have supported and encouraged the activities of pilgrimage, besides the spiritual needs of the people. The Paliyars used to gather the forest produce for the common markets and this practice must have increased in intensity in the colonial period. The hill was also a good source of timber, and the temple construction might have been one of the means of legitimization for the use of resources in the hill areas. Perhaps these resources were exploited by the Zamindaris. The reference to the hunting permits given to the tourists in the early $20^{\text {th }}$ century mentioned in the Railway guidebook does prove the active exploitation of the resources of the hills. The personal interest of the Saptur Zamindari seems to have supported the development of the temple. Thus, composite factors seem to have led to the development of the temple as an important pilgrimage centre. In addition, its natural secluded context offered peaceful path to fulfil the devotional spiritual aspirations of the people from the plains.

The contents of the Vazhinadaiccindu give glimpses of the perceptions of the period in which it was composed. The idea of pilgrimage perhaps dates back to the protohistoric period, in India, and in the historical period several temples become very popular among the people to fulfil their spiritual requirements and their wishes and prayers related to their mundane existence. Normally, offering worship in the shrines of the neighbourhood does not require much effort from the devotee. Generally, in pilgrimage the perception of higher virtue is that making strenuous efforts to visit a sacred location would mean higher dedication and thus would have more value, in this same way as the higher efforts produce higher yields. In the age of increased population, and settlements, and political changes around the $15^{\text {th }}$ to $20^{\text {th }}$ century, the shrines on the isolated hills and the forests in natural contexts, which were located away from the settlements, gave a solace to the pilgrims and visitors. Even today the hill temples of Sabarimala and Tirupati have higher spiritual value among the people, because of context of these shrines and also the efforts required to visit the temples, besides the belief systems. The underlying idea was that the higher the efforts put forth by a devotee, the closer to god s/he could become. From the ancient times, higher energy expenditure and wealth meant higher the chance for proximity to gods; and this notion is reflected in the special poojas and darshans offered in the contemporary religious institutions in many parts of the world. It is against such material value-oriented perceptions that the bhakti movement of the medieval South India emerged and it sought to simplify the mode of worship and approach to god, and helped to facilitate easier access to the gods. However, it is in the mind of the common people (or all Homo sapiens) that the degree of affection and quantum of outcome are conveyed by the value and quantity of the goods and gifts. This is how people even today nowadays determine quantity and value of their gifts and donations to various agencies right from their family members to the gods. The value attribution to social, political and economic status and proximity is a part of a cultural behaviour, which perhaps evolved in the prehistoric times. How can one express the variation in degree of affection and love? This idea is transformed into lower or higher value or lower or higher quantity goods. This correlation between human behavioural perception and material cultural value has been used by archaeologist to interpret the material culture found in the megalithic burials and other contexts. Thus, adoption of pilgrimage and Vazhinadaiccindu gave higher status to a particular shrine.

Despite the advancement of science, the behavioural area of belief is beyond rationalism among many common people. People as they have today, had their own mundane problems, for which they appealed to the gods and made offerings in the form of terracotta votive figures when fulfilled. Sometimes they prayed to visit the temple if their wish is fulfilled. When serious ailments afflict their sons or daughters people pray to god and vow to visit the temples at Tirupati, Pazhani or Velankanni church or Nagore Dargah even today.

The composer of the Vazhinadaiccindu describes the landscapes and the wealth of the village and the tradition of Mahamai. He mentions about Kshatriya Nadars in tandem with the social movements of those days. The various communities of this region and their activities are also spoken in this poem. The Vazhinadaiccindu is a means to explain the pathway to the temple and the landmarks that could be worshipped on the way. Such songs were also sung by the people to alleviate their tiredness during the pilgrimage.

Visiting temples and making offerings form part of an economic activity. The poem describes about the use of various objects for pooja, and the presence of shops selling goods is also indicated. The temples witnessed innumerable visitors, which boosted the economic activities and several traders must have set-up shops to sell diverse variety of goods on festival occasions. The above description of 
the Vazhinadaicccindu, Caturagiri temple and the history of Saptur Zamindar reveals that multiple factors contributed to the development of Caturagiri temple. The factors such as the development of print-culture, popularity of the cindu genre of literature and the interest of the merchants, and the spiritual needs of the people and also the patronage of Saptur Zamindari contributed to the development of Caturagiri temple and the composition of the Vazhinadaiccindu.

In an earlier paper, I had argued that the development of temple at Caturagiri gave access and rights to worship for the people from the plains in the Paliyar's exclusive area ${ }^{35}$. It is likely that the Paliyars supplied the forest produce and offered services to the people from the plains in the later medieval period, and this practice might have begun at an earlier period. During the enquiries conducted by me among the people of the Upper Gundar basin in 2000, the Moopars mentioned to me about their relationships with Paliyars and they stated that the Moopars were the elder brothers and the Paliyars were younger brothers. The Paliyars' territory has not been exclusive to the hills, and they come to the border areas of the Varushanadu hills and interact with the local people. The local people mentioned that the Paliyars moved into the hills permanently, since they could not pay "kisti" (tax to the government agencies), and this narration perhaps indicates that the Paliyars occupied the marginal area between the hills and the plains, and when the modern state or its agents sought to extract tax, they ventured into the hills. The attempt at taxing of Paliyars might have taken place around the time when the Palayakkarars or the Nayakkas dominated the political scenario in this region; the developments were also partly controlled by the emergeing British Colonial power. The Palayakkarars perhaps viewed the hill area as a resourcerich zone that could be used to generate additional income, and also as hunting territories. It possible that they used this forested area to escape from the activities of the colonial power. The development of temple gave easy access to the people from the plains into the forest area and led to the active exploitation of the resources of the area such as firewood, timber, a variety of forest produce and herbs, and wild animals. In addition, the temple and the festive occasions could have been convenient for the interactions between the Paliyans and the local people. The full moon or newmoon days would have been ideal time markers of the month that could be easily identified by people. The pilgrimage could have provided access to the traditional medicine of the Paliyars.

The publication of the Cindu song on the temple was in tune with the movement of those days where composition of these songs with the introduction of printing press, and publications in print became a kind of status for the shrine in the new context of print culture of the colonial times. The idea of Kshatriyar identity of the Nadar is highlighted by the composer of the Cindu.

Another important idea is that the Siddhas and their role in the development of traditional medicine. The Siddhas are considered alchemists and they practised yoga. They are attributed with several skills and knowledge set with supernatural powers and could solve mundane problems. Their period is generally placed around the $18^{\text {th }}$ century CE. The hunter-gatherers of the hill areas of South India had detailed knowledge of traditional medicine and they were offering the services to the people till the recent period; and some of them offer this service even today. The history of traditional medicine in the Upper Gundar Basin area near the Caturagiri hills extends back to the Sangam Age. A skeleton of a man in middle age excavated from a burial at S. Pappinyakkanpatti near Saptur has evidence for recovery and bone growth after an injury, suggesting the existence of traditional medicinal system (Figure 9) ${ }^{36}$.

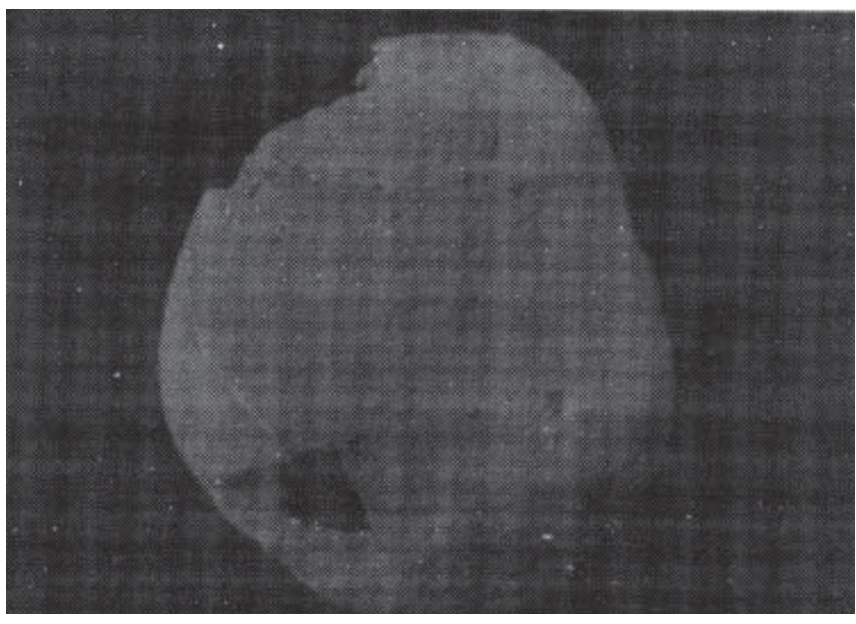

Figure 9. A Cranium with a cut-mark (injury) showing traces of recovery from S. Pappinayakkanpatti, Photo by Dr. S.R. Walimbe.

The Siddhas are often associated with various hills, which were also the abodes of the different hunter-gatherer groups, and a vast corpus of medicine. The Siddha medicine could be seen as a traditional knowledge system developed based on the understanding and knowledge of the Paliyars, and other hunter-gatherers of the hills. Perhaps the Siddhas might have interacted with Paliyars and other hill peoples, and it is possible that the Siddhas documented their medicinal practices. They might have validated the medicines through experiments. The Siddhas might have also consulted various old texts in the creation 
of the medicinal systems; it appears that the traditional knowledge of the hunter-gatherer communities might have gone into the making of the traditional Tamil Siddha medicine. Although it has been contented that the Paliyar Medicinal system is similar to the Siddha medicinal system, the degree of similarity has to be researched. Therefore, the hunter-gatherer source of Siddha medicine could be proposed as a hypothesis, which needs to be tested through further studies.

\section{Reference}

1. Catalogue number, P. Tam. C 2702. I would like to thank the British Library for the support, and the Nehru Trust for the Indian Collections at Victoria and Albert Museum for the UK visiting Fellowship, which helped in writing this paper. I would like to thank Dr. Sundar Kali for the comments on the draft of the paper, and Dr S. Darsana and Dr. P. Karthika for the support and comments.

2. There is another Vazhinadaiccindu on the Caturagiri temple, published from Madras in 1905 and available at Roja Muthiah Library, Chennai, which is not discussed here.

3. Selvakumar V. Archaeological Investigations in the Upper Gundar Basin, Madurai.

4. Gardner P. Op. cit. 2006.

5. Dakshinamurthy V. Paliyans Forests and Futures: An Ethnobotanical Investigation. PhD Dissertation, Gandhigram Rural Institute. 2007. http://hdl.handle.net/10603/110693.

6. Dahmen Rev F. The Paliyans, A hill-tribe of the Palni Hills (South India). Anthropos. 1908; 3:19-31; Census of India 1961: Paliyans. Census of India. 1961. Ethnographic Notes on Scheduled Tribes. 1964; IX(Part.V-B-(i)):195-248; Gardner, Peter M. Symmetric Respect and Memorate Knowledge: The Structure and Ecology of Individualistic Culture, Southwestern Journal of Anthropology. 1966; 22:389-415; Gardner, Peter M, Paliyan Social Structure, Contributions to Anthropology: Band Societies. Proceedings of the Conference on Band Organization, Ottawa, 1965 August 30 to September 2; (David Damas ed.), Ottawa, The National Museums of Canada. 1969; p. 153-71; Gardner, Peter M. The Paliyans, Hunters and Gatherers Today: A Socioeconomic Study of Eleven Such Cultures in the Twentieth Century, M.G. Bicchieri ed., New York, Holt, Rinehart and Winston. 1972; p. 404-47; Gardner, Peter M. Bicultural Oscillation as a Long-Term Adaptation to Cultural Frontiers: Cases and Questions. Human Ecology. 1985; 13:41132; Gardner, Peter M. Pragmatic Meanings of Possession in Paliyan Shamanism. Anthropos. 1991; 86:367-84; Gardner, Peter M. Forager's Pursuit of Individual Autonomy. Current Anthropology. 1991; 32(5):543-72; Gardner, Peter M. Respect and Nonviolence among Recently Sedentary Paliyan Foragers. Journal of the Royal Anthropological Institute. 2000 June; 6:215-36; Gardner, Peter M. Bicultural Versatility as a Frontier Adaptation among Paliyan Foragers of South India, New York,
The Edwin Mellen Press. 2000; Gardner, Peter M. Respect for All: The Paliyans of South India, Keeping the Peace: Conflict Resolution and Peaceful Societies Around the World, Graham Kemp and Douglas P. Fry eds., New York: Routledge. 2004; p. 53-71; Gardner, Peter M. Journeys to the Edge in the Footsteps of an Anthropologist, Missouri, University of Missouri Press. 2006; Tamilarasi Murugesan P and A Ananthalakshmi. Dietary Practices of the Paliyar Tribal Group and the Nutrient Content of Unconventional Foods Consumed. The Indian Journal of Nutrition and Dietetics. 1991; 28(12):297-301; Keystone Honey Hunters \& Beekeepers Survey Tamil Nadu - A survey document, Keystone, Pondicherry. 1994; and also see, Paper presented by the authors at the Apimondia Congress in Antwerp 1997 September; Bees for Development Journal. 45; Norstrom C. The Paliyans of Palni hills, Tamil Nadu, in A Handbook of the Anglade Institute of Natural History. Shembaganur KM. Matthew ed., Tiruchirapalli, The Rapinat Herbarium, 1994; Norstom C. Autonomy by default versus popular participation: the Paliyans of South India and the proposed Palni Hills Sanctuary, Identity and Gender in Hunting and Gathering Societies. Ian Keen and Jakako Yamada eds., Osaka, Japan: National Museum of Ethnology. 2001; p. 27-50; Norstrom C. They Call For Us Strategies for Securing Autonomy Among the Paliyans, Hunter-Gatherers of the Palni Hills, South India, Stockholm, Almqvist and Wiksell International. 2003; Nath Snehlata, Mathew John and Pratim Roy. The honey hunters of Tamil Nadu: Climbing through a period of change. 1995; FTP Newsletter 25. http://www-trees. slu.se/newsl/29/29nath.htm. Selvakumar V. Investigations into the Prehistoric and Protohistoric Cultures of the Upper Gundar Basin. Unpublished Ph.D. Thesis, Poona, University of Poona. 1996; Norman TSJ and V. Dakshinamurthy. A case Study of Paliyar Tribe of Sirumalai Hills. Gandhigram, The Center for Future Studies, Gandhigram Rural Institute, Deemed University. 2007.

7. Kevan Bundell. Rock Shelter Paintings - Sirumalai (Little Hills), Dindigul Dt, Tamilnadu, India. http://kevanbundell. co.uk/blog/category/rock-shelter-paintings-sirumalai/.

8. Winfred Thomas D, Oliver King EDI, Soundrapandi J and Narasimhan D. Evolution of Livelihood Strategies among Geographically Isolated Hill Tribes of South India, Interdisciplinary conference at the centre for Indian studies, Mysore, India. 2003; Ganesan, S, Suresh N and Kesaven L. Ethnomedicinal survey of lower Palni Hills of Tamil Nadu. Indian Journal of Traditional Knowledge. 2004; 3:299-304; Azhakar, Viruthunagar Mavattapp Pazhiyarkalin Vazhviyal, Rajapalayam, Vennila Pathippakam. 2005. Ignacimuthu S, Ayyanar M and SankaraSivaraman K. Ethnobotanical Investigations among Tribes in Madurai District of Tamil Nadu (India). Journal of Ethnobiology and Ethnomedicine. 2006; 2:25. Aavilable from: https://ethnobiomed.biomedcentral.com/articles/10.1186/1746-4269-2-25. https:// doi.org/10.1186/1746-4269-2-25 PMid:16689985 PMCid:PMC1475842. 
9. Little Layne. An Introduction to the Tamil Siddhas: Tantra, Alchemy, Poetics And Heresy Within The Context of Wider Tamil Shaiva World. Indian Folklife. 2003 April-June; 2 (Serial No. 13 Issue 4):19.

10. Kone G. 1940. Sathuragiri Thalapuranam Madurai, Pudumandapam Book House, as cited in Winfred Thomas et al. 2003; See note 2.

11. Francis W. Madura District Gazetteer, Madras, Government Press. 1906; p. 7.

12. Ibid. p. 7.

13. Rajendran P and Vedachalam V. Santhaiyur Seppedu -1, Tamizhakac Seppedukal, Sridhar ed., Chennai, Department of Archaeology, Government of Tamilnadu. 2005; p. 53-9; Rajendran P and Vedachalam V. Santhaiyur Seppedu -2, Tamizhakac Seppedukal, Sridhar ed., Chennai, Department of Archaeology, Government of Tamilnadu. 2005; p. 60-3.

14. Selvakumar V, Gandhirajan KT and Kannan S. Recent Archaeological Discoveries in The Usilampatti Area. Proceedings of Tamil Nadu Historical Congress, Vth Session, Thirunelveli. 1998; p. 93-6; Selvakumar V, Gandhirajan M and Kannan S. Usilampatti Paguthiyil Tholliyal Kandupidippugal. Avanam. 1999; 10:105-9; Selvakumar V. A Study of The Rock Art in The Upper Gundar Basin, Madurai District, Tamil Nadu, Exploring the Mind of Ancient Man: Festschrift to Robert G. Bednarik, P. Chenna Reddy ed., New Delhi. 2007; p. 380-8.

15. Gardner P. 2004; Op cit. p. 67; Gardner P. 2006; Op cit. p. $60-1$.

16. Thurston E and Rangachari. Castes and Tribes of Southern India. Madras: Government Press. 1909; 5.

17. Rajayyan K. South Indian rebellion: the first war of independence, 1800-1801, Mysore, Rao and Raghavan. 1971; p. 41, 77; Rajayyan K. Rise and fall of the poligars of Tamilnadu, Madras, University of Madras. 1974.

18. Rajayyan. 1971; p. 77; Udhayasankar I. The British diplomacy in Tirunelveli. PhD Dissertation, Bharathidasan University, Department of History. 1751-1803.

19. Rajayyan. 1971 ; p. 77.

20. Francis. Ibid. p. 329. Rajayyan. 1971; p. 41.

21. Ibid. p. 329.
22. Thurston E and Rangachari. Op cit. 1909; p. 190-191.

23. Vadivelu A. The Late M.R. RY Sri Nagayyaswami Kammayya Nayakkar Avarkal II Zamindar of Saptur, The Aristocracy of Southern India, Delhi, Mittal Publications 1906. 1984; 2:31521.

24. Madras Law Report XVII. 1894.

25. Selvakumar V. PhD. Dissertation. Op. Cit. Table 76.

26. Illustrated Guide to the South Indian Railway, Higginbotham and Co., Madras. 1900; p. 275.

27. Tirumurukan. Cintuppaatalkalin Yaappilakkanam. Madurai, Pavalar Pannai. 1993.

28. Venkatachalapathy AR. Anthakkaalatthil Kaappilllai, Chennai, Kalachuvadu. 2000; p. 130.

29. Ibid. p. 130.

30. Dipi Shadpak Dev JS. A Study on the Literary and Musical Excellences in the Compositions of Ramanathapuram Srinivasa Ayyangar. Ph.D. Dissertation, Department of Music, Kerala University. 2010; p. 76-7. http://hdl.handle. net/10603/168454.

31. There are many Kavadiccindu songs on the temples of Tamil Nadu and there is one on the Velappar temple of Mavuttu near Andipatti in Teni district of southern Tamil Nadu, and it was published by Sundar Kali and Parimalam. This temple is associated with a Paliyan population.

32. Sheeran Anne. Sri Lanka, The Concise Garland Encyclopedia of World Music. The Middle East South Asia, East Asia, Southeast Asia, Ellen Koskof, ed., New York, Routledge. 2008; 2:1069-74.

33. Selvakumar V. PhD. Dissertation, ibid. 1996; p. 171-205.

34. Evidence of wild buffalo bones has been excavated from the site of S. Pappinayakkanpatti, PhD Dissertation, Op. cit. 1996; Table 76.

35. Selvakumar V. How the Paliyans of Madurai were banished to the hills. Humanscape. 1999; 6(11):30-1.

36. Walimbe SR and Selvakumar V. Anthropological Investigations on An Iron Age Adult Male Skeleton from S. Pappinayakkanpatti, Madurai District, Tamil Nadu. Journal of Human Ecology. 1998; 9(Issue 1):19-34. https://doi.org/10. 1080/09709274.1998.11907329. 